http://doi.org/10.35784/iapgos.909

\title{
CLASSIFICATION OF MULTIDIMENSIONAL POLARIZATION MICROSCOPY RESULTS IN THE TECHNOLOGY OF FORENSIC INTELLECTUAL MONITORING OF HEART DISEASES
}

\author{
Oleg Vanchulyak ${ }^{1}$, Serhii Golub ${ }^{2}$, Mariia Talakh ${ }^{3}$, Vyacheslav Gantyuk ${ }^{3}$ \\ ${ }^{1}$ Bukovina State Medical University, Department of Forensic Medicine and Medical Law, Chernivtsi, Ukraine, ${ }^{2}$ Cherkasy State Technological University, Department \\ of Automated Systems Software, Cherkasy, Ukraine, ${ }^{3}$ Yuriy Fedkovych Chernivtsi National University, Department of Computer Science, Chernivtsi, Ukraine
}

\begin{abstract}
The work combines methods of multidimensional polarization microscopy, statistical processing of data and inductive modeling with the purpose of constructing a methodology for creation of intelligent systems for multi-level forensic medical monitoring based on the example of the post-mortem diagnosis of coronary heart disease and acute coronary insufficiency. The task of classifying the results of the study of biological materials for obtaining a diagnosis was solved. To obtain informative features, a model of biological tissue of the myocardium was developed and the main diagnostic parameters were determined (statistical moments of 1-4 orders of coordinate distributions of the values of azimuths and the ellipticity of polarization and their autocorrelation functions, as well as wavelet coefficients of the corresponding distributions), which are dynamic due to its necrotic changes. The classification of these data was provided by constructing a deciding rule in the multi - raw algorithm of the GMDH. The effectiveness of the described methodology has been experimentally proved.
\end{abstract}

Keywords: forensic medical monitoring, polarization microscopy, informative signs, classification

\section{KLASYFIKACJA WYNIKÓW WIELOWYMIAROWEJ MIKROSKOPII POLARYZACYJNEJ W TECHNOLOGII INTELIGENTNEGO MONITOROWANIA CHORÓB SERCA W MEDYCYNIE SACDOWEJ}

\begin{abstract}
Streszczenie. Praca łączy metody wielowymiarowej mikroskopii polaryzacyjnej, statystycznego przetwarzania danych i modelowania indukcyjnego w celu skonstruowania metodologii tworzenia inteligentnych systemów wielopoziomowego monitorowania w medycynie sadowej na przykładzie pośmiertnej diagnozy choroby wieńcowej $i$ ostrej niewydolności wieńcowej. Wykonano zadanie sklasyfikowania wyników badań materiałów biologicznych w celu uzyskania diagnozy. Aby uzyskać cechy informacyjne, opracowano model tkanki biologicznej mięśnia sercowego i określono główne parametry diagnostyczne (momenty statystyczne 1-4 rzędów wspótrzędnych rozkładów wartości azymutów i eliptyczności polaryzacji oraz ich funkcji autokorelacji. a także jako wspótczynniki falkowe odpowiadajacych im rozkładów), które sa dynamiczne z powodu jego zmian nekrotycznych. Klasyfikacja tych danych została zapewniona przez skonstruowanie decydujacej reguly w algorytmie multi-raw GMDH. Skuteczność opisanej metodologii została eksperymentalnie udowodniona.
\end{abstract}

Slowa kluczowe: monitoring medycyny sądowej, mikroskopia polaryzacyjna, znaki informacyjne, klasyfikacja

\section{Introduction}

Intelligent monitoring is a technology which provides information for decision-making processes, by organizing continuous observations and processing their results [1]. The main stages are to identify information about the objects' observation properties, which are needed to compare strategies during the decision-making, to identify the list of diagnostic parameters, which will be used for the formation of an array of input data (AID), to process and transform information by algorithms for synthesizing the models of the monitoring intellectual system (MIS). The set of the resulting classifier models is recorded in the base of model knowledge [2] and forms its hierarchical structure. It is always relevant to provide the AID informative, which is sufficient for constructing useful models by available methods and tools, which are implemented in the models synthesizer of MIS. Effective organization of research objects observations should involve of the latest scientific achievements in the subject area in which the monitoring technology is implemented.

The variety of medical monitoring facilities requires individual studies of the AID formation. The object of medical monitoring in this thesis are the processes of postmortem differentiation of coronary heart disease (CHD) and acute coronary insufficiency (ACI).

Cardiovascular diseases cause about a third part of the fatal consequences worldwide, taking the leading position among other causes of death [3,4]. Since 2000, cardiovascular diseases were the cause of $33.7 \%$ of the recorded deaths, and $42.5 \%$ among them were associated with CHD [5], in particular with sudden cardiac death due to ACI. The significant prevalence of ACI cases in the forensic practice and its suddenness, which causes suspicion of its violent nature, requires the use of objective and accurate methods. However, the ACI is difficult to diagnose through the nonspecificity of macroscopic features, the necessity of using specific methods of coloring and through the role of the "human factor" [6].
At the same time, the task of operational establishing of the AI remains unresolved. The existing shortage of modern, objective methods of determining the AI encourages the search and development of new technologies for monitoring the pathological changes in the human myocardium.

Methods of multidimensional polarization microscopy make it possible to formulate a list of informative indicators for the AID and to obtain their numerical characteristics containing new, objective information about the dynamics of changes in laser polarimetric images of the morphological structure of biological tissues. They have been successfully tested in solving such tasks as determining the prescription of death, forming hematomas, diagnosing the time of emergence of injuries and whether they were intra vitam injuries, or not $[7,8]$. In particular, the analysis results of distributions of polarization states (azimuths $\alpha$ and ellipticity $\beta$ ) and phases $(\delta)$ of light oscillations of myocardial images for the determination and displaying in numerical form of their changes associated with sources of AI in AID are quite informative $[9,10]$.

For the exploratory processing of the observation results obtained in this way and the construction of additional informative features, statistical, correlation, and wavelet analysis methods, followed by the definition of sensitivity $(S e)$, specificity $(S p)$, and balanced accuracy $(A c)$ are used $[11,12]$.

Thus, a vector of characteristics that describes the properties of each of the studied objects is formed. The set of numerical characteristics of feature vectors forms the AID. On its basis, the problem of classifying objects is solved by formation a resolving rule, which is used for putting characteristics vector of certain disease in correspondence to each disease. This decision rule is built by the models synthesizer of MIS. Now more than 20 algorithms for synthesis of models (ASM) were implemented in the synthesizer of MIS. These are the basic algorithms of the GMDH [13], GMDH-like algorithms, neural networks of various topologies, genetic and hybrid algorithms, etc. The synthesizer provides a choice of the algorithm for synthesis of models 
adaptively to the properties of the AID. The choice is based on the results of a sequential test of each of the ASM based on the quality of obtained model.

Thus, the process of disease diagnosis contains the stages of obtaining biological material, the formation of a list of its characteristics, the obtaining of a list of numerous characteristics, the formation of an array of input data, the construction of a decision rule by the synthesizer of MIS models, the classification of AID features, and interpretation of the results of the forensic expert classification. Models synthesizer used in the typical form, and the results of diagnostics depend on process of the AID formation. The studies results of biological samples using multidimensional polarization microscopy contain signs of the CHD and AID and allow to receive additional information for their diagnosis. Therefore, the study of the process of using multidimensional polarization microscopy for the formation of numerical features of the ACI and the synthesis of modelclassifiers is relevant. This technology makes it possible to increase the accuracy and reliability, which can ensure the forensic medical expert's decision-making process as to differentiation of the cause of the patient's death.

\section{Purpose and objectives of the study}

Step 1. Obtaining biological material

The basic formulated hypothesis was that a list of informative features for classification of diseases by information technology of multi-level intellectual monitoring in the forensic medical examination relating to the causes of patients' death provoked by cardiovascular diseases should be obtained by using multidimensional polarization microscopy methods for image processing of myocardium histological sections. The aim of the work is to study the process of forming a list of characteristics and forming an AID for the classification of the causes of patients' death for forensic medical examination by sequential application of multidimensional polarization microscopy methods, statistical data processing and inductive modeling.

\section{Results of the study}

At first, the classes have been formed and classification features of research objects have been allocated. For this purpose, three groups have been distinguished and the criteria for including objects in the classes and the criteria for their exclusion have been developed. All the dead persons were residents of the city of Chernivtsi and the region, which, according to relatives and results of forensic histological examination, did not have a significant systemic disease and they were not registered in this regard.

The parts of the myocardium of the people's corpses were investigated. The samples were carried out from various anatomical structures, including the sites of the membrane, the right and left ventricular walls, the right and left atrium walls, as well as the apex region of the heart. Blocks with a volume of $1 \mathrm{~cm}^{3}$ were formed, which were cut directly after sampling by freezing the microtome into sections of $30 \pm 5 \mu \mathrm{m}$ thick.
The characteristics of the classes of investigated objects are presented in the Table 1.

Stage 2. Formation of informative features of research objects

\subsection{Multidimensional polarization microscopy of histological sections of the myocardium}

Polarization microscopy was carried out at the standard location of the Stokes polarimeter [14].

The polarization irradiator consisted of two quarter-wave plates (Achromatic True Zero-Order Waveplate) and a polarizer (B + W Kaesemann XS-Pro Polarizer MRC Nano).

The myocardium cut was sequentially probed with a laser beam with the following types of polarization: linear with azimuths of $0^{\circ}, 90^{\circ}, 45^{\circ}$ and right circulation $(\otimes)$. Polarization images of the myocardium sample with the help of a polarizing micro-len 7 (Nikon CFI Achromat P, focal length $30 \mathrm{~mm}$, numerical aperture 0.1 , magnification $4 \mathrm{x}$ ) were projected into the plane of the photosensitive pad $(m \times n=1280 \times 960$ pixels $)$ of the CCD camera Imaging Source DMK 41AU02.AS, monochrome $1 / 2$ "CCD, Sony ICX205AL (progressive scan) resolution $1280 \times 960$, the size of the photosensitive pad is $7600 \times 6200 \mu \mathrm{m}$, the sensitivity is $0.051 \mathrm{x}$, the dynamic range is 8 bit. The analysis of images of the myocardial samples was carried out with the help of a polarizer and Quarter-wave plate.

Calculations of the coordinate distributions $V_{i}(p \times k)$ - Stokes vector parameters, $\alpha(p \times k)$ - polarization azimuths, $\beta(p \times k)-$ polarization ellipticities characterizing the microscopic images of the myocardial sections, were performed by using commonly known algorithms [15]:

$$
\begin{aligned}
& V_{i=1}^{0 ; 45 ; 90 ; \otimes}=I_{0}^{0 ; 45 ; 90 ; \otimes}+I_{90}^{0 ; 45 ; 90 ; \otimes} \\
& V_{i=2}^{0 ; 45 ; 90 ; \otimes}=I_{0}^{0 ; 45 ; 90 ; \otimes}-I_{90}^{0 ; 45 ; 90 ; \otimes} \\
& V_{i=3}^{0 ; 45 ; 90 ; \otimes}=I_{45}^{0 ; 45 ; 90 ; \otimes}-I_{135}^{0 ; 45 ; 90 ; \otimes} \\
& V_{i=4}^{0 ; 45 ; 90 ; \otimes}=I_{\otimes}^{0 ; 45 ; 90 ; \otimes}+I_{\oplus}^{0 ; 45 ; 90 ; \otimes}
\end{aligned}
$$

here $I_{0 ; 45 ; 90 ; 135 ; \otimes ; \oplus}$ is the radiation intensity transmitted by a linear polarizer with azimuth of rotation $0^{\circ}, 45^{\circ}, 90^{\circ}, 135^{\circ}$, and right $(\otimes)$ and left $(\oplus)$ circularly polarized filter.

Determining, according to (2), in each pixel of the photosensitive pad the set of Stokes parameters one can obtain the azimuth and polarization ellipticity at the corresponding points of the image of the native myocardial section:

$$
\begin{aligned}
& \alpha=0.5 \operatorname{arctg} \frac{V_{i=3}}{V_{i=2}} \\
& \beta=0.5 \arcsin \frac{V_{i=4}}{V_{i=1}}
\end{aligned}
$$

\begin{tabular}{|c|c|c|c|}
\hline Class & $\begin{array}{l}\text { Number of } \\
\text { objects in } \\
\text { the group }\end{array}$ & Inclusion criteria & Exclusion criteria \\
\hline 1. ACI & 150 & $\begin{array}{l}\text { a) people's corpses of two genders aged from } 18 \text { to } 45 \text { years; } \\
\text { b) histochemically confirmed by ACI }\end{array}$ & $\begin{array}{l}\text { a) the presence of anamnestic, macroscopic, microscopic, including } \\
\text { histochemical data of another pathology of the myocardium; } \\
\text { b) laboratory confirmed presence of some exogenous intoxication }\end{array}$ \\
\hline $\begin{array}{l}\text { 2. Chronic } \\
\text { ischemic heart } \\
\text { disease }\end{array}$ & 160 & $\begin{array}{l}\text { a) people's corpses of two genders aged from } 18 \text { to } 45 \text { years; } \\
\text { b) macroscopic signs: small focal myocardiosclerosis, the } \\
\text { presence of atherosclerotic plaques in the lumen of the } \\
\text { coronary arteries, hypertrophy of the ventricle left wall } \\
\text { (wall thickness } 1.6-2.0 \mathrm{~cm} \text { ), hypertrophy of the papillary } \\
\text { muscles, shortening of the mitral valve tendon }\end{array}$ & $\begin{array}{l}\text { a) postinfarction myocardiosclerosis; } \\
\text { b) the presence of anamnestic, macroscopic, microscopic, including } \\
\text { histochemical data of another pathology of the myocardium; } \\
\text { c) laboratory confirmed presence of some exogenous intoxication }\end{array}$ \\
\hline $\begin{array}{l}\text { 3. Control } \\
\text { group }\end{array}$ & 20 & $\begin{array}{l}\text { a) people's corpses of two genders aged from } 18 \text { to } 45 \text { years; } \\
\text { b) violent death with an absent agonal period }\end{array}$ & $\begin{array}{l}\text { a) the presence of anamnestic, macroscopic, microscopic, including } \\
\text { histochemical data of another pathology of the myocardium; } \\
\text { b) identification of agony features characteristic during the time of dying; } \\
\text { c) laboratory confirmed presence of some exogenous intoxication }\end{array}$ \\
\hline
\end{tabular}

Figure 1 illustrates a series of polarization images of an optically anisotropic matrix (in the crossed planes of transmission of the polarizer and the analyzer of myocardial tissue samples for all groups.

Table 1. Characteristics of classes of objects under study 

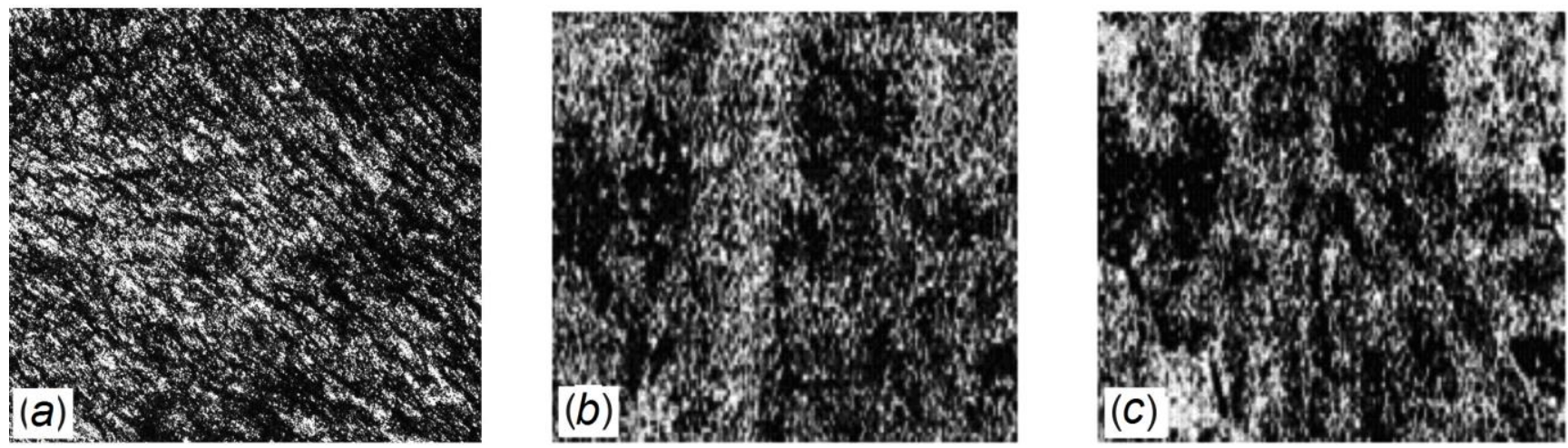

Fig. 1. Laser images of the fibrillar network of the histological section of the myocardium: (a) - an element of class 1; (b) an element of class 2; (c) an element of class 3

\subsection{Examination of myocardial tissue}

The following model representations are based on the description of the mechanisms of optical anisotropy of the myocardium $[16,17]$.

1. Amino acids and the polypeptide chains formed by them (the primary structure of the protein) have circular birefringence or optical activity and are characterized by the following matrix operator:

$$
\{\mathrm{A}\}=\left(\begin{array}{llll}
1 & 0 & 0 & 0 \\
0 & a_{22} & a_{23} & 0 \\
0 & a_{32} & a_{33} & 0 \\
0 & 0 & 0 & 1
\end{array}\right)
$$

where $a_{i k}=\left\{a_{22}=a_{33}=\cos 2 \theta\right\}$, here $\theta-$ the angle of rotation of the polarization plane of the light beam relative to the plane of incidence.

Thus, by recording the polarization azimuth of polarization map, it is possible to obtain information about the manifestations of optically active structures of the proteins primary structure that form the morphological structure of the myocardium.

2. Fibrillar (secondary structure) protein networks, which are formed by polypeptide chains, have linear birefringence. An optical manifestation of the morphological structure of the fibrillar network is the formation of the coordinate distribution of intensity in the plane within the microscopic image of the histological section of the myocardium. Optical manifestations of such a mechanism are amply described by the following matrix operator:

$$
\{B\}=\left(\begin{array}{llll}
1 & 0 & 0 & 0 \\
0 & b_{22} & b_{23} & b_{24} \\
0 & b_{32} & b_{33} & b_{34} \\
0 & b_{42} & b_{43} & d_{44}
\end{array}\right)
$$

where $b_{i k}=\left\{\begin{array}{l}b_{22}=\cos ^{2} 2 \gamma+\sin ^{2} 2 \gamma \cos \varphi \\ b_{23}=b_{32}=\cos 2 \gamma \sin 2 \gamma(1-\cos \varphi) \\ b_{33}=\sin ^{2} 2 \gamma+\cos ^{2} 2 \gamma \cos \varphi \\ b_{24}=-b_{42}=\sin 2 \gamma \sin \varphi \\ b_{34}=-b_{43}=\cos 2 \gamma \sin \varphi\end{array}\right.$

here $\gamma$ - the direction of laying of fibrils, which determines the orientation of the optical axis; $\varphi$ - phase shift between linearly polarized orthogonal components of the amplitude of the light beam.

Thus, by recording the elliptical polarization of polarization map, information can be obtained about the manifestations of the properties of fibrillar networks (networks) that form the secondary structure of the morphological structure of the myocardium.

3. Necrotic changes in the morphological structure of the myocardium lead to a structural and biochemical transformation of the primary and secondary structure of its protein components.
Optically, such processes lead to changes in the coordinate distributions of azimuth maps (biochemical processes) and ellipticity (orientational changes in fibrillar networks) of microscopic images polarization within the histological sections of the myocardium.

4. The main idea of differentiation of myocardial tissue samples of people who died as a result IHD or ischemic heart disease lies in the possibility of multi-parametrical $\left(r \equiv\left[\left(\begin{array}{l}\alpha \\ \beta\end{array}\right)\right]\right.$ ) objectification of the microscopic images analysis of histological sections within the framework of statistical, correlation and wavelet analysis. Statistical analysis of the results was carried out by calculating statistical moments of $1,2,3$, and 4 orders of magnitude (mean, variance, asymmetry, kurtosis) of digital camera pixels of the Stoks-Polarimeter which records the native cut and polarization-filtered microscopic images of the myocardium.

The correlation analysis was performed by calculating the auto-correlation function by the coordinate displacement along the rows of digital camera pixels of the coordinate distributions according to the known relation. In order to quantify the autocorrelation function $K(r)$, we used calculations of the statistical moments of the second (relation (4)) and the fourth (relations (6)) orders (here and further correlation moments $K_{2}$ and $K_{4}$ ). The wavelet analysis was performed for local estimation of coordinate distributions [18]. As an analytical probe, a special mathematical function (wavelet function) was used, which has a finite basis both in the coordinate and frequency space. Using the wavelet function, the values distribution of the calculated parameter $q$ that characterizes the image structure of the native myocardium slice was decomposed into a mathematical series representing the convolution (correlation) of the displacement parameters (b) and scaling (a) and certain coefficients (wavelet coefficients). The result of the wavelet transformation of the one-dimensional parameter dependence is a two-dimensional array of amplitudes of the wavelet coefficients $W(a, b)$. The wavelet analysis makes it possible to investigate the multi-scale structure of polarization maps, which are interrelated with the morphological structure of myosinovirus myocardial networks.

To characterize the informative value of the diagnostic method the objective parameters, called operational characteristics were used. They include sensitivity $(S e)$, specificity $(S p)$ and balanced accuracy (Ac) [10]. Sensitivity shows what will be the proportion of expert cases in which this study will give a positive result. The higher sensitivity of the test indicates that with the help of it the disease will be diagnosed more often, hence it is more effective. Having the determined specificity, it is possible to assume a priori what is the proportion of healthy individuals among which this study will give a negative result. The higher specificity of the method indicates reliability of the expert conclusion. So the higher specificity, thus it also proves the effectiveness of the test. Accuracy (balanced accuracy) shows how many correct results were obtained during the application of this investigation method. This criterion is also called diagnostic effectiveness. 
Stage 3. Formation of an array of input data (AID)

Thus, the list of informative features contains statistical moments of 1-4 orders of coordinate distributions of the azimuths and ellipticity values of of polarization and their auto-correlation functions, as well as the wavelet coefficients of the corresponding distributions. An array of input data (AID) was formed by calculating the multiple specific characteristics and their combination into a two-dimensional array of data in accordance with methodology described here [1]. The numerical characteristics of the image of an individual biological sample make it possible to form a line in a two-dimensional AID table the observation point in the multidimensional feature space. The AID contained 306 observation points, which were used to construct the model and 24 points - for testing the model.

Each observation point was classified expertly according to Table 1 - 1) ACI 2) CHD and 3) control without the features of these diseases. Affiliation to class 1 was affected by "+10", to class 2 - "10", in class 3 - "0". Table 2 shows a fragment of an array of input data, on the basis of which the model was synthesized.

Under the research conditions, the model-classifier provided the correct results of disease identification at all observation points. This means that the AID is quite informative. And the hypothesis of the formation of the AID based on the results of the consistent application of multidimensional polarization microscopy methods has been experimentally confirmed.

Table 2. Fragment of an array of input data

\begin{tabular}{|c|c|c|c|c|c|c|c|}
\hline Class & $\mathrm{x}_{1}$ & $\mathrm{x}_{2}$ & $\mathrm{x}_{3}$ & $\mathrm{x}_{4}$ & $\mathrm{x}_{5}$ & $\ldots$ & $\mathrm{x}_{144}$ \\
\hline 10 & 0.6856 & 0.0901 & 0.2901 & 1.1917 & 0.2603 & $\ldots$ & 0.4404 \\
\hline 10 & 0.6805 & 0.0901 & 0.2907 & 1.1914 & 0.2593 & $\ldots$ & 0.4416 \\
\hline 10 & 0.6769 & 0.0902 & 0.2895 & 1.2127 & 0.2606 & $\ldots$ & 0.4425 \\
\hline 10 & 0.6867 & 0.0902 & 0.2899 & 1.1885 & 0.2595 & $\ldots$ & 0.4399 \\
\hline$\ldots$ & $\ldots$ & $\ldots$ & $\ldots$ & $\ldots$ & $\ldots$ & $\ldots$ & $\ldots$ \\
\hline-10 & 0.633 & 0.1099 & 0.2401 & 1.565 & 0.2301 & $\ldots$ & 0.3202 \\
\hline-10 & 0.6302 & 0.1010 & 0.2399 & 1.5279 & 0.2307 & $\ldots$ & 0.3200 \\
\hline-10 & 0.6282 & 0.1101 & 0.2396 & 1.565 & 0.2297 & $\ldots$ & 0.3196 \\
\hline-10 & 0.6264 & 0.1010 & 0.2391 & 1.5386 & 0.2295 & $\ldots$ & 0.3204 \\
\hline-10 & 0.6284 & 0.1100 & 0.2399 & 1.5371 & 0.2305 & $\ldots$ & 0.3205 \\
\hline$\ldots$ & $\cdots$ & $\cdots$ & $\ldots$ & $\ldots$ & $\ldots$ & $\ldots$ & $\ldots$ \\
\hline 0 & 0.1601 & 0.3398 & 0.6127 & 0.1300 & 0.1301 & $\ldots$ & 0.2099 \\
\hline 0 & 0.1598 & 0.3403 & 0.6099 & 0.1302 & 0.1300 & $\ldots$ & 0.2099 \\
\hline 0 & 0.1599 & 0.3398 & 0.6117 & 0.1300 & 0.1302 & $\ldots$ & 0.2100 \\
\hline 0 & 0.1600 & 0.3398 & 0.6049 & 0.1300 & 0.1300 & $\ldots$ & 0.2100 \\
\hline 0 & 0.1602 & 0.3394 & 0.6086 & 0.1299 & 0.1299 & $\ldots$ & 0.2101 \\
\hline ... & $\cdots$ & $\cdots$ & $\ldots$ & $\cdots$ & $\cdots$ & $\ldots$ & $\cdots$ \\
\hline
\end{tabular}

Stage 4. Synthesis of model-classifiers

Model-classifiers were built using the multi-row algorithm of the GMDH [13]. Several algorithms for the synthesis of models implemented in the MIS were sequentially tested. Based on the test results, the ASM was selected, which provides the best performance characteristics of the model-classifier by the regularity criterion on the examination sequence of observation points.

The table 3 shows the results of the research. The value of the image indicated the belonging of the observation point to one of the 3 classes. The modeling result reflects the calculated value of the image.
Table 3. Results of testing the model-classifier on the examination (test) sequence

\begin{tabular}{|c|c|c|}
\hline Class & Real value of affiliation & Real value of affiliation \\
\hline 1 & 10 & 9.99 \\
\hline 1 & 10 & 10 \\
\hline 1 & 10 & 9.99 \\
\hline 1 & 10 & 10 \\
\hline 1 & 10 & 9.99 \\
\hline & $\ldots$ & $\cdots$ \\
\hline 2 & -10 & -10 \\
\hline 2 & -10 & -10 \\
\hline 2 & -10 & -10 \\
\hline 2 & -10 & -9.99 \\
\hline 2 & -10 & -10 \\
\hline & $\ldots$ & $\ldots$ \\
\hline 3 & 0 & -37 \\
\hline 3 & 0 & -30 \\
\hline 3 & 0 & -51 \\
\hline 3 & 0 & -99 \\
\hline 3 & 0 & -50 \\
\hline
\end{tabular}

\section{Conclusions}

The use of monitoring information systems to provide information for decision-making processes in the field of forensic medical examination allows to solve successfully the classification problems of the samples. It was shown that the use of statistical processing of the results of the myocardial tissue studies by the methods of multivariate polarization microscopy allows to obtain statistical moments of $1,2,3$, and 4 orders, which are informative and can be used to form the AID during the model-classifiers construction of the test samples.

The effectiveness of using inductive modeling methods, in particular the multi-row algorithm GMDH, is experimentally confirmed. It is used to synthesize the classifier models based on the AID with the results of image processing of myocardium sections by polarization microscopy methods.

A set of methods for obtaining biological samples, the formation of informative features, the construction of modelclassifiers and the interpretation of modeling results are forming the information technology of intellectual forensic medical monitoring.

\section{References}

[1] Bachinskyi V. T., Boychuk T. M., Ushenko A. G., Dubolazov A. V., Vanchuliak O. Ya., Ushenko Yu. A., Ushenko V. A.: Laser polarimetry of biological tissues and fluids. LAP Lambert Academic Publishers, 2017.

[2] Davis C. S.: Statistical Methods of the Analysis of the repeated measurements. Springer-Verlag, New York 2002.

[3] Dubolazov O. V., Ushenko A. G., Bachynsky V. T. et al.: On the feasibilities of using the wavelet analysis of Mueller matrix images of biological crystals. Advances in Optical Technologies 2010, 162832.

[4] Garazdyuk M. S., Bachinskyi V. T., Vanchulyak O. Ya., Ushenko A. G., Dubolazov O. V., Gorsky M. P.: Polarization-phase images of liquor polycrystalline films in determining time of death. Appl. Opt. 55/2016, 67-71.

[5] Gerrard A., Burch J. M.: Introduction to Matrix Methods in Optics. Dover Publications, Inc., New York 1994.

[6] Golub S. V.: Multilevel modeling in environmental monitoring technologies. ChNU named after Bogdan Khmelnitsky, Cherkassy 2007.

[7] Ivakhnenko A. G.: Inductive method of self-organization of models of complex systems. Science. Thought, Kiev 1981. 
[8] Lopera G., Curtis A. B.: Risk stratification for sudden cardiac death: current approaches and predictive value. Curr. Cardiol. Rev. 5/2009, 56-64.

[9] Mozaffarian D., Benjamin E. J., et al.: Heart disease and stroke statistics-2015 update: a report from the American Heart Association. Circulation 131(4)/2015, 329-322.

[10] Petrie B. Sabin: Medical Statistics at a Glance. Blackwell Publishing, 2005.

[11] Rubart M., Zipes D.: Mechanisms of sudden cardiac death. Journal of Clinical Investigation 115(9)/2005, 2305-2315.

[12] Sakhnovskiy M. Yu., Ushenko Yu. O., Ushenko V. O., Besaha R. M., Pavlyukovich N., Pavlyukovich O.: Multiscale polarization dianostics of birefringent networks in problems of necrotic changes dianostics. Proc. SPIE $10612,2018,106121 \mathrm{~K}$

[13] Ushenko G., Dubolazov A.V., Ushenko V. A., Ushenko Yu. A., Pidkamin L. Y., Soltys I. V., Zhytaryuk V. G., Pavlyukovich G. N.: Muellermatrix mapping of optically anisotropic fluorophores of molecular tissues in the diagnosis of death causes. Proc. SPIE 9971, 2016, 99712L.

[14] Ushenko Y. A., Arkhelyuk A. D., Sidor M. I., et al.: Laser polarization autofluorescence of endognous porphyrins of optically anisotropic biological tissues and fluids in diagnostics of necrotic and pathological changes of human organs. Appl. Opt. 53/2014, B181-B191.

\section{D.Sc. Oleg Vanchulyak}

e-mail: sudmed@bsmu.edu.ua

Bukovina State Medical University

D.Sc. (medical), Associate Professor of Forensic Medicine and Medical Law. Research interests: forensic traumatology, diagnostics of limitation of onset of death, establishment of limitation and survivability of causing bodily injury, use of methods of correlation optics in forensic medicine.. Author of nearly 250 publications in this research area.

http://orcid.org/0000-0003-0243-1894

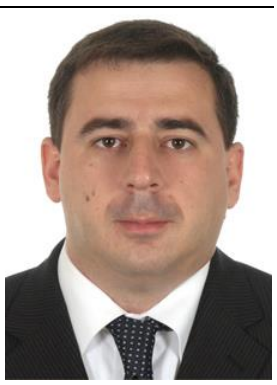

D.Sc. Serhii Golub
e-mail: fpkpk@ukr.net

\section{Cherkasy State Technological University}

D.Sc. (technical), Professor, of the Department of Automated Systems Software. Research interests: Information technologies of intellectual monitoring, inductive modeling, intellectual analysis of texts, systems of artificial intelligence, systems and methods of decision-making. Author of nearly 300 publications in this research area.
[15] Ushenko Yu. A., Sidor M. I., Pashkovskaia N., Koval G. D., Marchuk Yu. F., Andreichuk D.: Laser polarization-variable autofluorescence of the network of optically anisotropic biological tissues: diagnostics and differentiation of early stages of cancer of cervix uteri. Journal of Innovative Optical Health Sciences $7(6) / 2014,1450024$

[16] Ushenko Yu. A., Bachynsky V. T., Vanchulyak O. Ya., Dubolazov A. V., Garazdyuk M. S., Ushenko V. A.: Jones-matrix mapping of the complex degree of mutual anisotropy of birefringent protein networks during the differentiation of myocardium necrotic changes. Appl. Opt. 55/2016, B113-B119.

[17] Ushenko Y. O., Dubolazov O. V., Karachevtsev A. O., Gorsky M. P., Marchuk Y. F.: Wavelet analysis of Fourier polarized images of the human bile. Appl. Opt. 51/2012, 133-C139.

[18] Van der Werf C., Hofman N., Tan H. L., et al.: Diagnostic yield in the young: the experience of a tertiary referral center in The Netherlands Heart Rhythm., 7(10)/2010, 1383-1389.

[19] Zhiriakova I. A., Golub S. V.: A new approach to the conceptualization of knowledge. Technical sciences and technology $2 / 2015,78-82$.

\section{Ph.D. Mariia Talakh \\ e-mail: flaredreem@gmail.com}

Yuriy Fedkovych Chernivtsi National University.

Ph.D. (biological), Assistant, Department of Computer Science. Research interests: methodology of creation of automated systems of ecological monitoring, geoinformation systems, intellectual analysis of geospatial data. Author of nearly 50 publications.

http://orcid.org/0000-0002-5523-6120

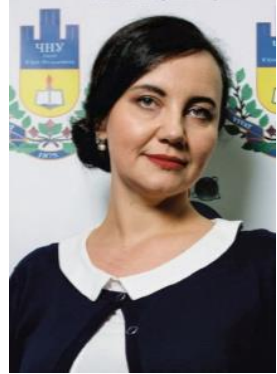

Ph.D. Student Vyacheslav Gantyuk e-mail:Vgantyuk2@gmail.com

Yuriy Fedkovych Chernivtsi National University. $\mathrm{Ph} . \mathrm{D}$ Student at Department of Computer Science. Research interests: Data science methodology in life sciences.

http://orcid.org/0000-0003-0792-5113

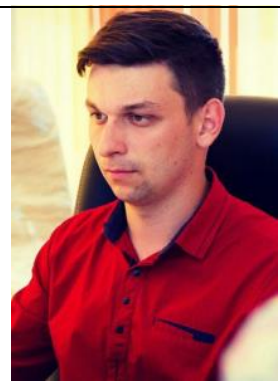

